\title{
Two New Generic and Three Specific Records of Lemnaceae to the Aquatic Flora of Iraq
}

\author{
Abdulridha A. Alwan Al-Mayah ${ }^{1} \&$ Sahar A. Malik Al-Saadi ${ }^{1}$ \\ ${ }^{1}$ Department of Biology, College of Science, Basrah University, Basrah, Iraq \\ Correspondence: Sahar A. Malik Al-Saadi, Department of Biology, College of Science, Basrah University, \\ Basrah, Iraq. Tel: 964-078-0141-8698. E-mail: saharmalik2010@gmail.com
}

Received: August 2, 2012 Accepted: September 5, 2012 Online Published: October 16, 2012

doi:10.5539/jps.v2n1p18 URL: http://dx.doi.org/10.5539/jps.v2n1p18

\begin{abstract}
In this study two genera Spirodela Schleiden, and Landoltia Les \& Crawford were recorded for the first time for flora of Iraq. Each genus represented by one species, these species is Spirodela polyrhiza (L.) Schleiden and Landoltia punctata (G. Meyer) Les \& Crawford. In addition one more species of the genus Lemna (L. minuta) was added to the flora of Iraq for the first time too. Brief descriptions with main distinguishing characters for the three new recorded species were provided. Habitat and geographical distribution were mentioned .Floral and fruit characters for Lemnaceae species from Iraqi material were tabulated and illustrated for the first time. A key to all species of Lemnaceae in Iraq was provided.
\end{abstract}

Keywords: Lemnaceae, aquatic plants, morphology, taxonomy, description, Iraq

\section{Introduction}

The family Lemnaceae includes six genera and thirty species distributed in freshwater habitat in most part of the world, and only one genus Lemna, with four species, L. gibba L., L. minor L., L. perpusilla Torr. and L. trisulca L. have been found in Iraq (Townsend \& Guest, 1985). It is a family of very small aquatic plants including duckweed Lemna and the smallest known flowering plant Wolffia (Heywood, 1978). Species of Lemnaceae are important as a source of food for water fowl and fish. They are considered as an excellent food for hens, geese and ducks because they contain a large amount of protein and a small quantity of cellulose (Culley \& Epps, 1973; Rusoff, Blakeney, \& Culley, 1980; Men, Ogle, \& Lindberg, 2002).

Duckweed species of Lemnaceae are usually floating or free floating or submerged. The floating species grow so densely that the marsh or the pool appear green with no water surface be shown they grow very well in still water. The presence of duckweeds in a water body can be used as an ecological indicator for pollution and high nitrification (Reid, 2004). Duckweed growth may be inhibited by many physiological factors such as water temperature above $35^{\circ} \mathrm{C}$, a $\mathrm{pH}$ higher than 10 , a deficiency of nitrogen. Species of Lemnaceae are rarely collected in flower and often reproduced a sexually, this means that flowering and fruiting occur in stress conditions such as winter or other unfavorable or severe conditions (Skillicorn, Spira, \& Journey, 1993), a good number of them lack clarity for proper recognition and identification, the lack of clarity in identity is due to their small size, much reduced plant body (Halder \& Venu, 2012)

Rechinger (1964) mentioned only one species of Lemna (L. minor) to occur in Iraq, Al-Rawi (1964) mentioned three species L. minor, L. gibba, L. trisulca, Townsend and Guest (1985) mentioned four species of Lemna and the same number was confirmed by Alwan (2006) to be historically occurred in Iraq, but only L. minor was recollected after the reflooded of the marshes in 2004-2005. The present study is part of an attempt to study morphology, ecology and distribution of new species of the family in Iraq, as well as description, diagnosis and key for all species were provided.

\section{Materials and Methods}

Six stations, two in each marsh of Al-Hewaiza, Al- Chebaish and Al-Hammar were chosen for monthly sampling (Figure 1). Electrical conductivity (Ec) determined by conductivity meter model (CC-41-EKMETRON), dissolved oxygen (DO) were measured according to (Lind, 1979). The PH was determined using a $\mathrm{pH}$ meter model Hi 8424, also used Horribia multimeter systems were used for measuring $\mathrm{pH}, \mathrm{Ec}(\mathrm{ms} / \mathrm{cm})$ and $\mathrm{DO}(\mathrm{mg} /$ L). 
Samples and specimens were collected monthly from January to November 2007. Plant specimens were fixed in F.A.A. (formalin $5 \mathrm{ml}$, acetic acid $5 \mathrm{ml}: 90 \mathrm{ml}$ from $70 \%$ ethanol). Herbarium specimens were also prepared and deposited in BSRA (Basrah University Herbarium).Features of thallus, roots and flowers were studied using a light microscope and photographed by using Canon SD750 camera at different magnification.

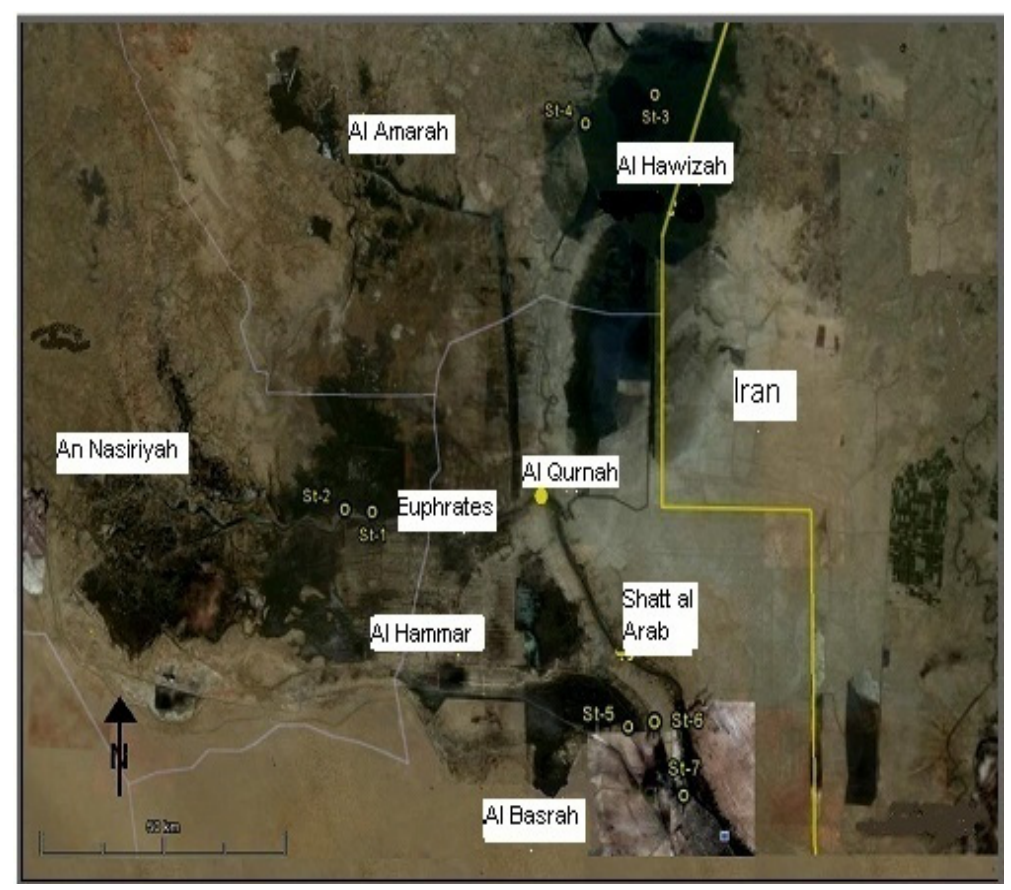

Figure 1. Map of the southern Iraq marshes showing samples stations

St-1: Abo Cholan; St-2: Abo Sobat; St-3: Um-A-Naage; St-4: Um-Al-Warid; St-5: Burga; St-6: Nagara.

\section{Results and Discussion}

Lemna species are small not exceeding $4 \mathrm{~mm}$ in length, lemna thalli have a single root, which distinguishes them from related species Spirodela and Landoltia, which contain several roots (Figure 2 and Figure 3). Because of the very small size, simple thallus structure and similarity in morphology of Lemnaceae species, it appears for most collectors that all green mass of the duckweed that cover the surface of water are belonging to the same species (one species) of Lemna .And because of all species of Lemnaceae are often grow together in same region, and usually asexually reproduced and flowers are rarely seen, it is very difficult to distinguish them in the field. That is the reason why many species were overlooked by previous workers such as (Al-Rawi, 1964; Rechinger, 1964; Al-Mayah, 1978; Al-saadi \& Al-Mayah, 1983) and other workers. However, Townsend and Guest (1985) and Al-Mayah and Al-Hamim (1991) mentioned that for Lemnaceae, only one genus , Lemna , has been recorded in Iraq, but it is very possible that others have been overlooked such as Spirodela polyrrhiza and Wolffia arrhiza (rootless species).

In this study and during a year of survey and sample collection, three species of Lemnaceae were recorded for the first time for the flora of Iraq; these were Spirodela polyrrhiza (L.) Schleid, Landoltia punctata (G.Mey.) Les \& Crawford and Lemna minuta Kunth.

Lemna minuta Kunth is also a new record for the flora of Iraq it is closely related to Lemna minor but can easily be distinguished from it by having much smaller size of thallus, with no grooves beneath (Figure 2). L. minor Thallus dark green, symmetrical, flat, oblong-ovate, $1.5-4 \mathrm{~mm}$ long, $0.75-3 \mathrm{~mm}$ wide, without large airspaces evident beneath. Root solitary arising along a shallow groove, root-cap obtuse. While in L.gibba thallus flattened, broadly ovate in outline, yellow-green, asymmetrical (oblique), or slightly convex, $2.5-5 \mathrm{~mm}$ long, $1.5-4 \mathrm{~mm}$ wide (Table 1, Figure 2 and Figure 3), almost hemispherical below and spongy cells with large inflated hyaline cells and airspaces. 
Table1. Measurements of species of Lemnaceae

\begin{tabular}{|c|c|c|c|c|c|c|c|}
\hline \multirow[t]{2}{*}{ Species } & \multicolumn{2}{|c|}{ Thallus } & \multirow{2}{*}{$\begin{array}{l}\text { Nerves } \\
\text { number }\end{array}$} & \multirow{2}{*}{$\begin{array}{c}\text { Filament } \\
\text { length } \\
(\mathrm{mm})\end{array}$} & \multirow[t]{2}{*}{ shape } & \multirow{2}{*}{$\begin{array}{l}\text { Root } \\
\text { lenth } \\
(\mathrm{cm})\end{array}$} & \multirow[t]{2}{*}{$\begin{array}{l}\text { Root } \\
\text { number }\end{array}$} \\
\hline & Length(mm) & Width(mm) & & & & & \\
\hline \multirow[t]{2}{*}{ Lemna gibba } & $(2.5-5)$ & $(1.5-4)$ & \multirow{2}{*}{3} & \multirow{2}{*}{1.24} & \multirow{2}{*}{ broadly ovate } & $(1.5-6)$ & \multirow{2}{*}{1} \\
\hline & 3.23 & 2.6 & & & & 4.03 & \\
\hline \multirow[t]{2}{*}{ Lemna minor } & $(1.5-4)$ & $(0.75-3)$ & \multirow{2}{*}{3} & \multirow{2}{*}{1.27} & oblong & $(10-0.8)$ & \multirow{2}{*}{1} \\
\hline & 2.75 & 1.29 & & & obovate & 4.08 & \\
\hline \multirow[t]{2}{*}{ Lemna minuta } & $(1-3)$ & $(1-2)$ & \multirow{2}{*}{1} & \multirow{2}{*}{1.53} & \multirow{2}{*}{ oblong obovate } & $(0.5-4)$ & \multirow{2}{*}{1} \\
\hline & 2.3 & 1.5 & & & & 3.2 & \\
\hline \multirow[t]{2}{*}{ Spirodela polyrrhiza } & $(2-5)$ & $(2-3.1)$ & \multirow{2}{*}{$4-10$} & \multirow{2}{*}{1.61} & \multirow{2}{*}{ elliptic-obovate } & $(1.2-6)$ & \multirow{2}{*}{$5-15$} \\
\hline & 3.77 & 2.33 & & & & 3.4 & \\
\hline \multirow[t]{2}{*}{ Landoltia punctata } & $(5-7.3)$ & $(2-5)$ & \multirow{2}{*}{$4-18$} & \multirow{2}{*}{1.21} & \multirow{2}{*}{ rounded-obovate } & $(1.3-5.5)$ & \multirow{2}{*}{$2-8$} \\
\hline & 5.75 & 4.75 & & & & & \\
\hline
\end{tabular}

The genera Spirodela and Landoltia recorded for the first time in this study, both can easily be distinguished from Lemna by having numerous roots, purple colour beneath and obviously larger size. Spirodela differ from Landoltia by having more number of roots (5-15) obvious veins on thallus and gradually acute root tip (Table 1, Figure 2 and Figure 3). It is worthy to mention that the genus Landoltia has been recently proposed by (Les and Crawford, 1999) with only one species L. punctata. He considered his genus as an intermediate between Spirodela and Lemna and it represents an isolated distinct clade from both.

Table 2. Measurements of species of Lemnaceae

\begin{tabular}{|c|c|c|c|c|c|c|c|c|}
\hline \multirow[t]{2}{*}{ Species } & \multicolumn{2}{|c|}{ Fruit length (mm) } & \multirow[t]{2}{*}{$\begin{array}{l}\text { Style length } \\
\quad(\mathrm{mm})\end{array}$} & \multicolumn{2}{|c|}{ Ovary (mm) } & \multirow{2}{*}{$\begin{array}{c}\text { Filament } \\
\text { length } \\
(\mathrm{mm})\end{array}$} & \multicolumn{2}{|c|}{ Anther (mm) } \\
\hline & Length & Width & & Length & Width & & Length & Width \\
\hline Lemna & $(1-2.25)$ & $(1-2.25)$ & $(0.10-0.50)$ & $(0.5-0.5)$ & $(0.5-0.5)$ & $(1-2.25)$ & $(0.10-0.25)$ & $(0.15-0.25)$ \\
\hline gibba & 1.54 & 1.52 & 0.25 & 0.5 & 0.5 & 1.72 & 0.20 & 0.21 \\
\hline Lemna & $(1-2)$ & $(1-2)$ & $(1.10-0.25)$ & $(0.25-0.5)$ & $(0.25-0.5)$ & $(0.25-0.75)$ & $(0.10-0.25)$ & $(0.10-0.25)$ \\
\hline minor & 1.23 & 1.1 & 0.19 & 0.38 & 0.34 & 0.58 & 0.17 & 0.16 \\
\hline Lemna & $(0.5-1.5)$ & $(0.25-0.5)$ & $(0.10-0.25)$ & $(0.10-0.25)$ & $(0.10-0.25)$ & $(0.25-0.50)$ & $(0.10-0.25)$ & $(0.10-0.25)$ \\
\hline minuta & 1 & 0.34 & 0.12 & 0.15 & 0.15 & 0.42 & 0.13 & 0.12 \\
\hline Landoltia & $(1.5-2.5)$ & $(1-2)$ & & & & $(0.25-0.75)$ & $(0.10-0.30)$ & $(0.25-0.50)$ \\
\hline punctata & 2.22 & 1.53 & - & - & 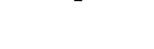 & 0.44 & 0.25 & 0.37 \\
\hline $\begin{array}{l}\text { Spirodela } \\
\text { polyrrhiza }\end{array}$ & - & - & - & - & - & - & - & - \\
\hline
\end{tabular}



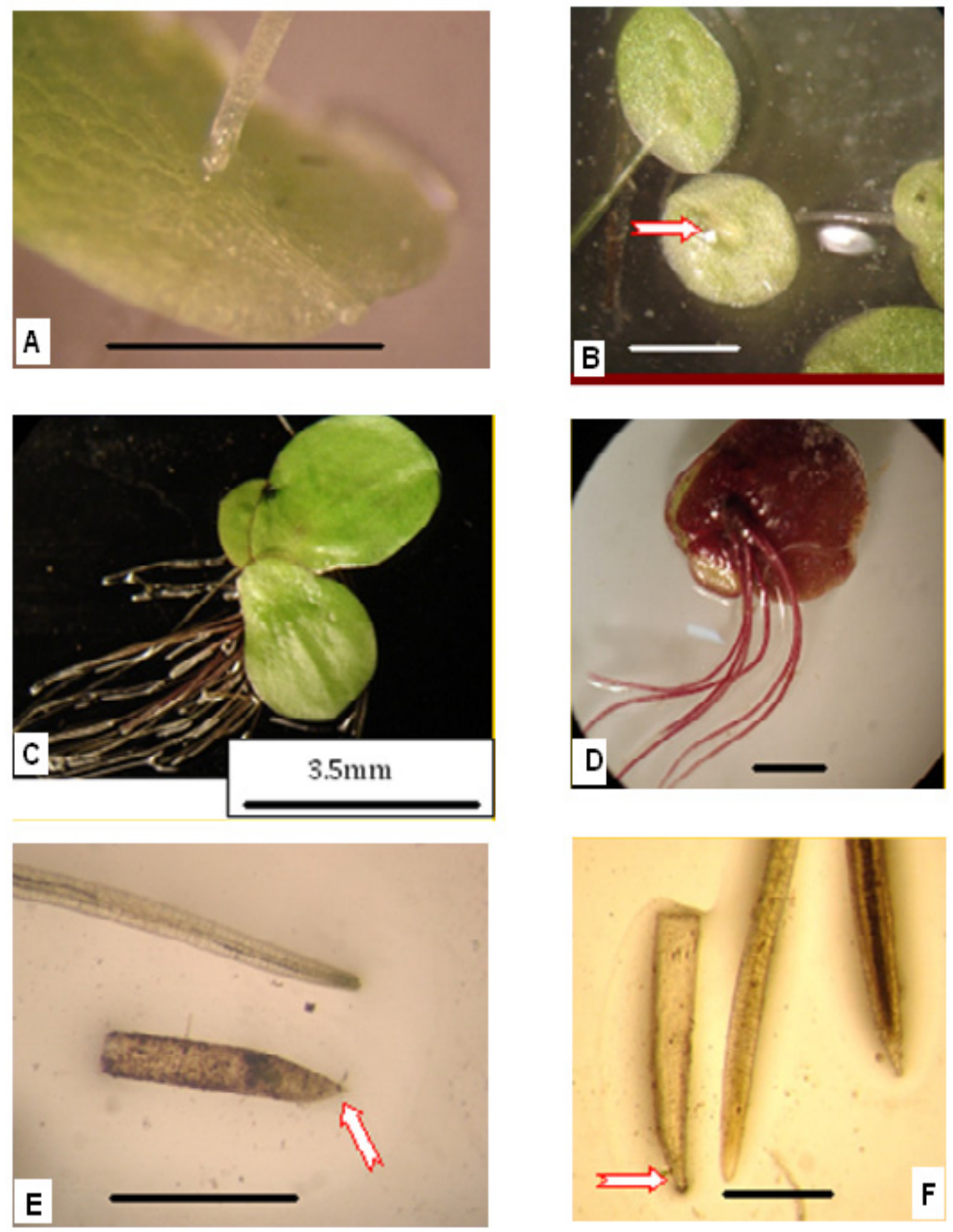

Figure 2. The differentiation between the roots in species of Lemnaceae (1 mm)

A: Lemna minuta (without groove); B: Lemna minor (with groove);

C: Spirodela polyrrhiza (roots on lower surface); D: Landoltia punctata;

E: Spirodela polyrrhiza (acute root tip); F: Landoltia punctata (rounded root tip). 

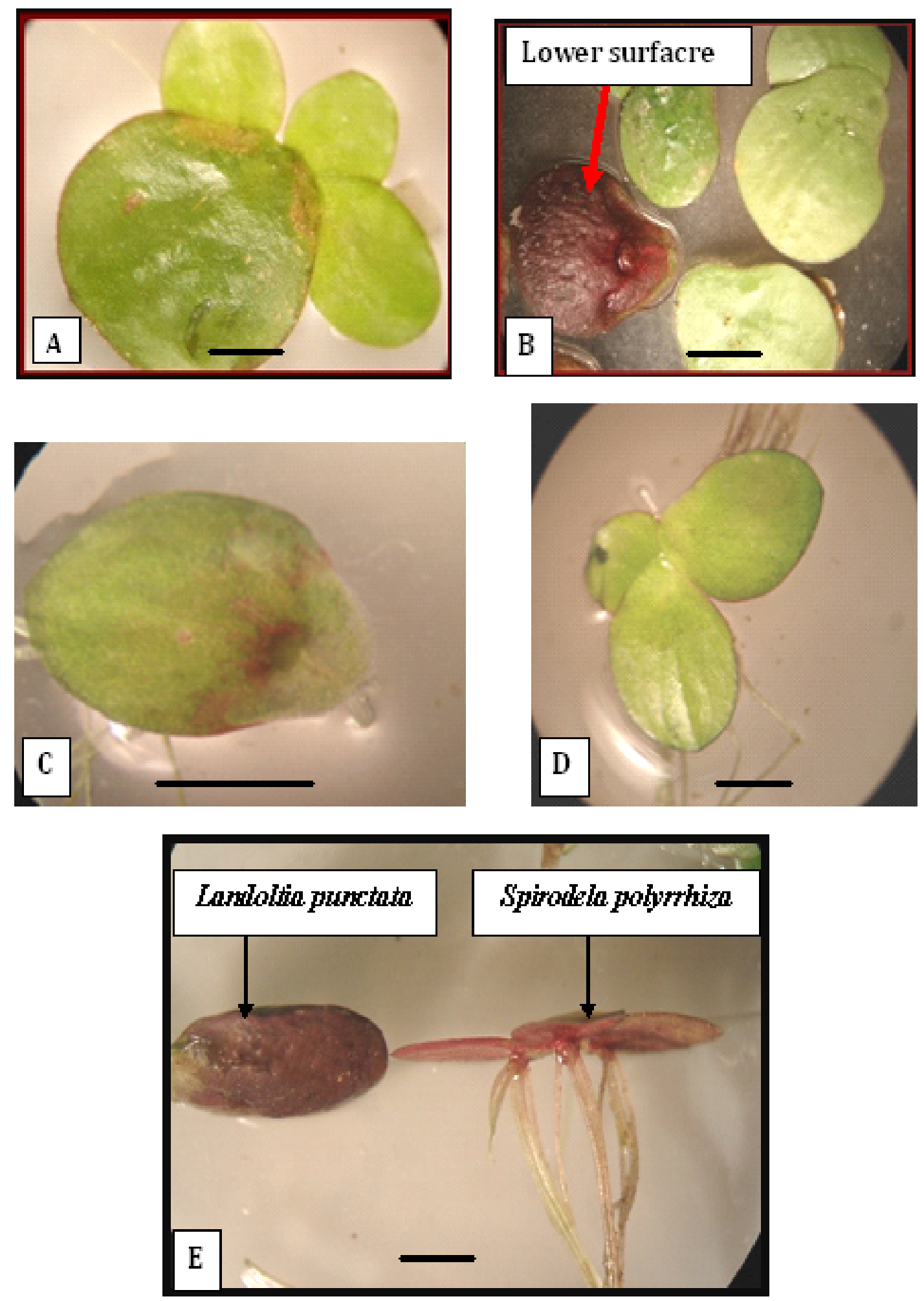

Figure 3. The differentiation between Landoltia punctata and Spirodela polyrrhiza $(1 \mathrm{~mm})$

A, B: Landoltia punctata (A-upper surface B- lower surface);

C, D: Spirodela polyrrhiza (upper surface);

E: variation in thallus thickness 

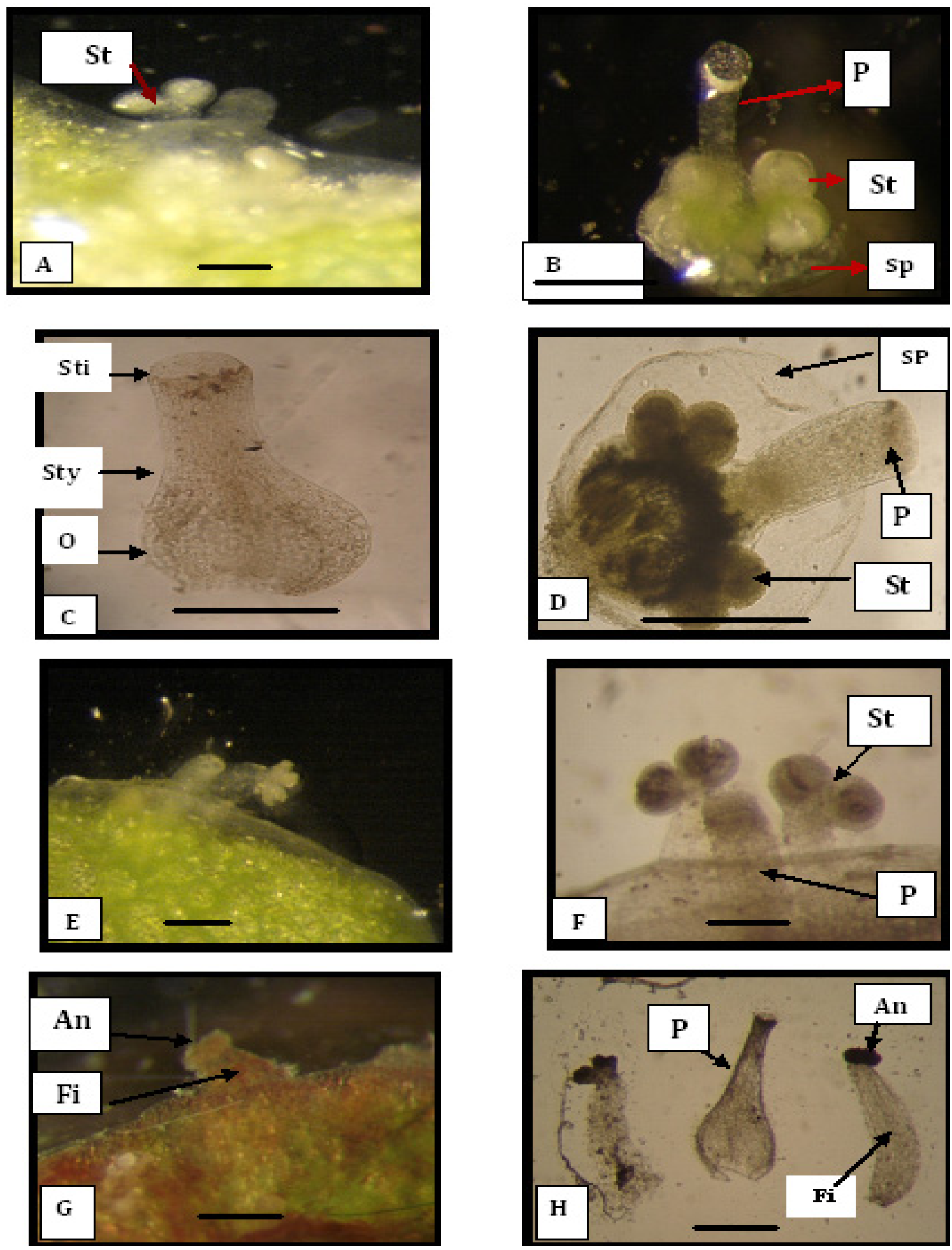

Figure 4. The differentiation between flowers in species of Lemnaceae $(0.25 \mathrm{~mm})$

A, B: Lemna minor ; C: Lemna minuta (Pistal); D: L.minuta (spathe open from one side);

E, F: Lemna gibba (flowers); G: Landoltia punctata H: Lemna gibba (Pistal and stamen);

P: Pistal; St: Stamen; Sp: Spathe membrane; Sti: Stigma; Sty: Style O-Overy; An: Anther; Fi: Filament.

Figure 4 appear Inflorescence Lemna and Landoltia in full bloom in lateral pouch, Lemna gibba showed that tow stamens and a short style are projecting from a lateral budding pouch at the base of the plant .The androecium 
consist of tow pollen-bearing stamens. The gynoecium consist of a single pistil with concave stigma, slender style and basal ovary $(0.5 \mathrm{~mm})$ (Table 2$)$. The bisexual flower is enclosed within a membranous saclike spathe within the budding pouch in L.gibba while In L.minor floral pocket lateral, spath open at the top. Staminate flower two each with a single stamen (Figure 4).

L.minor may be readily distinguished by the lack of a conspicuous wing on the fruits and the seed 1-2 but in L.gibba the seeds 2-4. Moreover, the spathe is comparatively shorter. L.minuta different from Lemna minor and L. gibba spathe open down one side, seeds solitary (Figure 5). These results agree with (Manson, 1957). Fruits winged at the shoulder in Lemna gibba but other species the fruit not winged at the shoulder (Figure 5). The range of large fruit was recorded in Landoltia punctata was $2.22 \mathrm{~mm}$, while smaller was recorded in Lemna minuta $1 \mathrm{~mm}$ (Table 2).
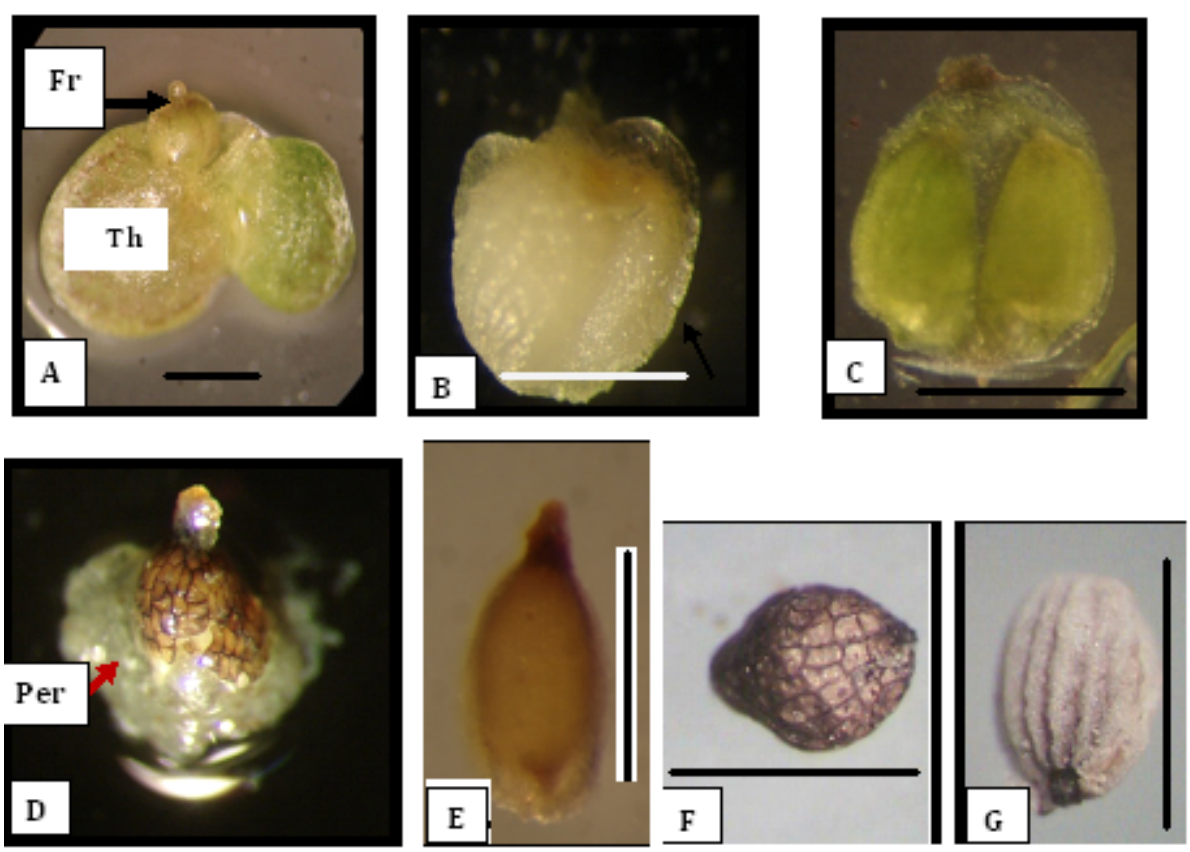

Figure 5. The differentiation between fruits and seeds inspecies of Lemna (1mm)

A, B: Lemna gibba (winged fruit); C: Lemna minor (unwinged fruit); D: Lemna minuta (seed);

E: Lemna minuta(fruit); F: Lemna minor (seed); G: Lemna gibba (seed); Fr: fruit; Th: thallus; Per:pericarp

Depending on our results the Lemnaceae in Iraq now includes three genera and seven species and can be identified by the following key.

\section{A key to the Lemnaceae of Iraq:}

1- Thallus with only one root, obscurely 1-3 nerved $-3($ Lemna $)$

1- Thallus with more than one root, 4-18 nerved

2-Thallus with 5-15 roots, with clearly visible nerves on thallus, root tip gradually acute Spirodela polyrrhiza

2-Thallus with 2-8 roots, flat, with hardly visible nerves on thallus, root tip rounded Landoltia punctata

3-Thallus obviously stalked, toothed at the top, usually submergent -Lemna trisulca

3-Thallus neither stalked nor toothed, free floating $-4$

4-Thallus hemispherical gibbous or sometimes flat form but always with large inflated cells and --airspaces beneath L. gibba

4-Thallus neither gibbous nor with large inflated cells and airspaces beneath 5 
5- Sheath of root winged below the thallus L. perpusilla

5- Sheath of root not winged below the thallus $-6$

6- Root arising in a groove below the thallus L. minor

6- Root not arising in a groove below the thallus L. minuta

\subsection{Description of the Three New Recorded Species of Lemnaceae in Iraq}

3.1.1 Spirodela polyrrhiza (L.) Schleid (Table1, Table 2, Figure 1 and Figure 2)

Synonym: Lemna polyrrhiza $\mathrm{L}$.

Diagnostic and important characters

Thallus, with 5-15 roots, elliptic obovate or sometimes round, purple beneath, with 5-15 roots, 2-5 mm long and 2-3.10 mm wide, solitary or in group, root tip acute.

Distribution: LSM: Hewaiza marsh, Um- Al-Naaje and Um-Al-warid (April-November, 2007), LBA Shatt Al-Arab (April- December, 2007).

Habitat: Floating on surface of water, flowers and fruits. Not seen.

Environmental conditions: Water temperature ranged $18-28{ }^{\circ} \mathrm{C}, \mathrm{pH}$ was 7.03 in winter to 8.6 during summer; Salinity up to $10 \mathrm{pp}$.

3.1.2 Landoltia punctata (G. Mey) Les \& Crowford (Table 1, Table 2, Figure 1 and Figure 2)

Synonym: Lemna punctata G. Mey

Thallus, with 2-8 roots, rounded or broadly obovate, reddish-purple beneath and dark green above, 5-7.3 mm long and 2-5 $\mathrm{mm}$ wide, nerves hardly visible, root tip obtuse.

Distribution: LSM, Hewaiza marsh, Um-Al-Naaje and Um-Al-warid (April- November, 2007).

Habitat: Floating on the surface of water, flowers \& fruits. May to July

Environmental conditions: Water temperature ranged $18-28{ }^{\circ} \mathrm{C}, \mathrm{pH}$ was 7.03 in winter to 8.6 during summer; Salinity up to $10 \mathrm{ppt}$.

\subsubsection{Lemna minuta Kunth}

Thallus very small, 1-3 mm long and 1-2 mm wide, dark green, oval- oblong in outline, symmetrical, solitary or in pairs. Root not arising in a groove below the thallus.

Distribution: LSM, Hewaiza marsh, Um-Al-Naaje; LBA, shatt Al-Arab.

Habitat: Floating of surface of water, flowers \& fruits, April to Jun.

Environmental conditions: Water temperature ranged $18-28{ }^{\circ} \mathrm{C}, \mathrm{pH}$ was 7.03 in winter to 8.6 during summer; Salinity up to $10 \mathrm{ppt}$.

Note: As mentioned by Townsend and Guest (1985) in Flora of Iraq that flowers of Lemna have not yet observed in Iraqi material it is necessary to give illustration for it from our data as in (Table 2, Figure 4 and Figure 5).In conclusion, the data obtained from morphological studies were useful for taxonomic purposes in the Iraq.

\section{References}

Al-Mayah, A. A. (1978). Common water and marsh angiosperms of southern Iraq. J. Bang. Aca. Sci, 2(2), 47-54.

Al-Mayah, A. A., \& Al- Hamim, F. I. (1991). Aquatic plant, and the Algae (pp. 699-701). Univ. Basrah (in Arabic).

Al-Rawi, A. (1964). Wild plants of Iraq. Ministry of Agriculture and Irrigation (p. 225), Abo Ghiraib-Iraq.

Al-saadi, H. A., \& Al-Mayah, A. A. (1983). Aquatic plants of Iraq. Cent. Arab. Gulf. Univ. Basrah . (Arabic).

Alwan, A. A. (2006). Past and present status of the aquatic plants of the marshlands of Iraq. Marsh Bull, 2(1), $160-172$.

Culley, D. D., \& Epps, E. A. (1973). Use of duckweed for waste treatment and animal feed. J. Wat Poll Cont. Fed, 45(2), 337-347.

Halder, S., \& Venu, P. (2012). The taxonomy and report of flowering in Lemna L. (Lemnaceae) in India. Current science, 102(12), 1629-1632. 
Heywood, V. H. (1978). Flowering plants of the world. Oxford Uni. Press. Oxford.

Les, E., \& Crawford, J. (1999). Landoltia (lemnaceae), A new genus of duckweeds. Novon, 9, 530-533. http://dx.doi.org/10.2307/3392157

Lind, O. T. (1979). Handbook of common methods in limnology (p.190).

Mason, H. (1957). Flora of the Marshes of California (pp. 327-343). University of California press . London.

Men, B. X., Ogle, B., \& Lindberg, J. E. (2002). Use of duckweed as a protein supplement for breeding ducks. Asian-Aust. J. Anim. Sci. 15(6), 886 -871.

Rechinger, K. H. (1964). Flora of Lowland Iraq. (pp. 140-141). CHR. Belser, stuttdart, Weinheim.

Reid, W. S. (2004). Exploring duckweed (Lemna gibba) as a protein supplement for ruminants using the boer goat (Capra Hircus) as a model. A thesis submitted to the Graduate Faculty of north Calrolina State University, 1-91.

Rusoff, L. L., Blakeney, J. R., \& Culley, D. D. (1980). Duckweed (lemnaceae family): A potential source of protein and amino acids. J. Agric. Food Chem, 28, 848-850. http://dx.doi.org/10.1021/jf60230a040

Skillicorn, P., Spira, W., \& Journey, W. (1993). Duckweed aquaculture a new aquatic farming system for developing countries. The world Bank. Washington, 76.

Townsend, C. C., \& Guest, E. (1985). Flora of Iraq (pp. 203-208). Ministry of agriculture and agrarian reform republic of . Baghdad. Iraq. 